Лю Кетін,

кандидат мистецтвознавства, викладач музичної школи в Гуанчжоу (КНР)

ORCID 0000-0003-1326-1210

576471513@qq.com

\title{
СТИЛЬОВІ ДОМІНАНТИ КИТАЙСЬКОГО МИСТЕЦТВА ХХ СТОЛІТТЯ Й ХУДОЖНЯ ПРАКТИКА ТАЙВАНЮ
}

\begin{abstract}
Метою статті $є$ з'ясування специфіки взаємодії всекитайської культурної традиції з регіональною культурною якістю музичного Тайваню, який географічно й політично опинився в активній й історично неоднозначній взаємодії з материковим китайським мистецтвом з 1950-х pp. до кінця ХХ сторіччя. Методологічною основою роботи є інтонаційний підхід, що фіксує єдність музичного й мовного факторів, який $є$ органічним для традицій музики Китаю (див. роботи Ма Вей та ін.) Компаративний метод у методологічному комплексі інтонаційності здобуває самозначимий зміст - у дусі відповідних робіт Б. Асафьєва i його послідовників в Україні. Особливий методологічний зміст мають також праці Лю Бінцяна, що актуалізують проблему духовно-семантичної обумовленості кардинальних стильових поворотів у світовому мистецтві й у культурі в цілому. Наукова новизна дослідження визначається новаційністю ідеї тайваньського стилістичного внеску в загальнокитайський стильовий запас, у якому офіційний академізм і вірність національним умовам породили глибоко оригінальну версію модерну ХХ століття. Висновки. Історичними шляхами центральний Китай у XX ст., насамперед, його великі культурно-художні центри Пекін і Шанхай, виявилися спрямованими на проєвропейські шляхи в музично-освітній системі по лінії зв'язку з Росією як військовою спільницею у війні з Японією ще від початку ХХ століття й аж до подій Другої світової війни (див. діяльність М.Черепнина в Китаї). Тайвань у художньому аспекті позначився становленням в істотній опорі на західні впливи. Внутрішньокитайські культурні показники визначили самостійність Тайваню в схильності до вокально-пісенної й фортепіанної сфер, тоді як в області театру відповідні акценти позначилися всюди, окрім Тайваню.
\end{abstract}

Ключові слова: стиль в музиці, стильові домінанти, стиль китайського мистецтва XX сторіччя, стиль художньої практики Тайваню.

Лю Кетин, кандидат искусствоведения, преподаватель музыкальной школы в Гуанчжоу (КНР)

Стилевые доминанты китайского искусства $\mathrm{XX}$ века и художественная практика Тайваня

Целью статьи является выяснение специфики взаимодействия всекитайской культурной традиции с региональным культурным качеством музыкального Тайваня, географически и политически оказавшегося в активном и исторически неоднозначном взаимодействии с материковым китайским искусством с 1950-х гг. до конца XX столетия. Методологической основой работы является интонационный подход, фиксирующий единство музыкального и речевого факторов, что органично для традиций музыки Китая (см. работы Ма Вэй и др.). Компаративный метод в методологическом комплексе интонационности приобретает самозначимый характер - в духе соответствующих работ Б. Асафьева и его последователей в Украине. Особый методологический смысл имеют также труды Лю Бинцяна, поднимающие проблему духовно-семантической обусловленности кардинальных стилевых поворотов в мировом искусстве и в культуре в целом. Научная новизна исследования определяется новационностью идеи тайваньского стилистического вклада в общекитайский стилистический запас, в котором официальный академизм и верность национальным условиям породили глубоко оригинальную версию модерна XX века. Выводы. Историческими путями центральный Китай в XX в., прежде всего, его великие культурно-художественные центры Пекин и Шанхай, оказались направленными на проевропейские пути в музыкально-образовательной системе по линии связи с Россией как военной союзницей в войне с Японией еще от начала XX века и вплоть до событий Второй мировой войны (см.деятельность Н.Черепнина в Китае). Тайвань в художественном плане обозначился становлением в существенной опоре на Западные влияния. Внутреннекитайские культурные показатели определили самостоятельность Тайваня в отзывчивости на вокально-песенную и фортепианную сферы, тогда как в области театра соответствующие акценты обозначились всюду, помимо Тайваня.

Ключевые слова: стиль в музыке, стилевые доминанты, стиль китайского искусства XX века, стиль художественной практики Тайваня.

Liu Ke Ting, PhD of Arts, teacher music school in Guangzhou (China)

Style predominates chinese art XX century and artistic practice Taiwan

The Purpose of the Article is a clarification of the specifics of the interaction Pan-China cultural tradition with regional cultural quality of musical Taiwan, geographically and political turned out to be in active and historically ambiguous interaction with continental chinese art with 1950-th before the end XX centuries. The methodology of the 
work is intonation approach, fixing unity music and speech factor that органично for tradition of the music of China (refer to work Ma Way and others. Komparativ method in methodological complex intonation theorises gains the independent character - in spirit corresponding to work of B. Asafiev and his followers in Ukraine. The special methodological sense has also works of Liu Bing Cjiang, raising the problem of spiritual-semantic determinism of cardinal style tumbling in world art and in culture as a whole. Scientific novelty of the study is defined innovations of the idea Tasivan stylistic contribution to Pan-China stylistic spare, in which official academism and faithfulness national condition has generated deeply original version of the modernist style XX century. Conclusions. The history fetter central China in XX c., first of all, his great cultural-artistic centres Peking and Shanghai, turned out to be to be directed on European character of the way in music-educational system on communication link with Russia as military confederate in war with Japan else from begin XX century and up to event of the Second World War (N.Cherepnin in China). Taiwan in artistic plan was marked by formation in essential full tilt on West influences. Inner-China cultural factors have defined the independence of Taiwan in responsiveness on vocal-singing and piano spheres than in the field of theatre corresponding to accents were marked aside from Taiwan.

Key words: style in music, style predominates, style chinese art XX century, style artistic practical of persons Taiwan.

Актуальність дослідження задана потребами національного мистецтва сучасності, у якій полінаціональні культурні рішення утворюють живу складну ієрархічність і в якій генеральні лінії ціннісних переваг наповнюються динамікою регіональних наробітків. «Сучасний літературний рух 1960-х», що висунув тайваньський художній колорит у фокус всенаціональної уваги, склав органічне продовження проверистських установок китайської художньої культури початку ХХ століття.

Проблеми китайського мистецтва ХХ століття у зв'язку 3 його регіональними проявами зачіпалися неодноразово, у тому числі це видані в Китаї й в Україні праці Сюй Ченбея, Лю Бінцяна [8; 4], Ту Дуні, Ло Куня, ін., статті Е.Виноградової і А.Желоховцева в енциклопедичних виданнях [3], ін. Однак спеціально мистецтво Тайваню в його співвідношенні 3 китайським художнім феноменом XX століття не обговорювалося в зазначених і інших працях.

Метою статті є з'ясування специфіки взаємодії всекитайської культурної традиції 3 регіональною культурною якістю музичного Тайваню, який географічно й політично опинився в активный й історично неоднозначній взаємодії з материковим китайським мистецтвом 3 1950-х рр. до кінця ХХ століття.

Методологічною основою роботи є інтонаційний підхід, що фіксує єдність музичного й мовного факторів, якийц є органічним для традицій музики Китаю (див. роботи Ма Вей та ін.) Компаративний метод у методологічному комплексі інтонаційності здобуває самозначимий зміст - у дусі відповідних робіт Б. Асафьєва і його послідовників в Україні. Особливий методологічний зміст мають також праці Лю Бінцяна, що актуалізують проблему духовно-семантичної обумовленості кардинальних стильових поворотів у світовому мистецтві й у культурі в цілому.

Мистецтво Китаю силою історичних обставин у ХХ сторіччі виявилося утягненим в активну взаємодію з європейським світом, у тому числі це участь на стороні Росії в Російсько-японській війні й згодом антияпонська ж позиція в подіях середини ХХ століття. Але при цьому Тайвань виявився під японською окупацією, що визначило деякі важливі переваги в художній сфері останнього. Участь у європейських політичних перипетіях визначили соціальні потрясіння Китаю. Ідеї інтернаціоналізму, що проникнули в китайський соціум, намітили чітку установку на впровадження музичного утворення європейського типу, що й було здійснено від 1920-х років.

Одночасно китайський феномен активно обговорювався в європейському ареалі, породжуючи нові запозичення, паралелі й взаємодії. У дослідженні Лю Бінцяна відзначені «хвилі» китайського впливу на європейський культурний світ і співвіднесені з ними хронологічні й фактологічні етапи завоювань китайського мистецтва XX століття [4, 255-285]. Дивні зустрічні спрямованості цих, що зовсім автономно зароджувалися, рухів.

Так, захват символістів Свропи, в особі П.Клоделя, М.Волошина, К. Дебюссі, Г.Малера й ін. у зв'язку з пізнаванням у китайському феномені забутих цінностей готично-ренесансної Свропи мав певну - недетерміновану - реакцію в проверистській «літературі рідних місць», у центрі якої виявився китайський заломлений феномен А.Чехова (Лу Сінь - «китайський Чехов»).

Участь у європейських політичних перипетіях визначили соціальні потрясіння Китаю. Ідеї інтернаціоналізму, що проникли в китайський соціум, намітили чітку установку на впровадження музичної освіти європейського типу, що й було здійснено від 1920-х років.

Модерністський вихід Б. Брехта 3 його комуністично-агітаційною програмою мав ніби продовження в будівництві Сяо Юмеєм європеїстського принципу музичної освіти в Китаї. А от 3 1950-х рр. політично й музично Китай наполегливо виявляється у впливі на Європу, що завершилося 
торжеством прокитайськи вибудуваної творчості корейця Ісанга Юна й китайця Тан Дуна в композиторській творчості, які вперше виявили участь в ії системі неєвропейських авторів, до речі, що надзвичайно активно виявили свою національну приналежність у творчості.

Сказане дозволяє пояснити сприятливий художній контекст, що формував контакт мистецтва Тайваню $з$ материковим Китаєм при всіх жорсткостях політико-ідеологічних розбіжностей, що устанавлювалися протягом другої половини XX сторіччя.

Китайське музичне мистецтво середини XX століття пережило підйом, що визначив зліт кінця минулого сторіччя: від оригінальних пошуків «Сивої дівчини» Ма Ке й спектаклів Культурної революції - до композиторського підняття Тан Дуна, що став кульмінаційною точкою художнього сходження Китая в XX столітті. В роботі Лю Бінцяна дана наступна характеристика цього епохального моменту в житті китайського музичного мистецтва:

«3'єднання театрального досвіду Китаю i Європи здійснено тут, як це видно із сьогоднішнього дня, дуже сміливо, майже на грані театру абсурду. Відмітимо, саме в 1950-ті у Франції румун Іонеско та ірландець Беккет вибудували тип вистави, що одержав назву 'театру абсурду'. Але в ті ж 1950-ті роки Л. Бернстайн створює 'драматичний мюзикл'... ... є зазначені епохальні риси - в 'Сивій дівчині' китайських авторів» [4, 174-175].

Далі названий автор уточнює:

«...3 погляду і європейської, і китайської традиції в опері 'Сива дівчина' є риси абсурдизму. ...Революційні події в китайській провінції - і одночасно головна героїня, її оточення показані ...у балетній європейській стилістиці 'танцю на пуантах'(!). Таке з'єднання 'високого' і 'низького' у стилі, національного й позанаціонального в композиції й прийомах, дійсно, об'єктивно свідчать про абсурдистсько-експериментальний характер вистави» $[4,175]$.

Наведені характеристики свідчать надзвичайно плідну атмосферу буття Китаю в 1950-ті роки, коли Тайвань був уведений до складу КНР. Одночасно із зазначеними проявами оригінальних ліній національного театру в Китаї бурхливо розвивається тут європейська система музики, у тому числі це інтенсивний розвиток фортепіанної школи, підготовлене титанічними зусиллями по впровадженню в китайську систему музичної освіти досвіду європейських консерваторій. У роботі В.Батанова виокремлено ім'я Сяо Юмея як одного із найбільш послідовних і талановитих музикантів, що поступнево й глибоко здійснював впровадження європейської системи «музики для слухання» у мистецтво Китаю [2, 133].

В іншій книзі Лю Бінцяна представлена ємна характеристика звершень етапу Культурної революції 1960-х років, коли в числі «8 кращих вистав» опинилися опера цзінцзюй і балет «Жіночий батальйон Червоної Армії» [4, 309-310]. Названий автор докладно пояснює органіку того, що ставлося у національному театрі Китая, де визначилася установка на актуалізацію традиції в контексті завдань мистецтва XX століття в цілому:

«Балетний варіант вистави утворив автономізований принцип виконання балетних складових цзінцзюй, пекінської опери, які в цьому типі національного театру надзвичайно значимі й навіть в окремих випадках (див. 'Потрійна розвилка', 'Дебош у Небесному палаці'...) заміняють спів як такий» $[4,310]$.

Вище вже відзначалося, що пекінська опера має два напрямки: 'цивільні' і 'військові' п'єси. 3 них перші, в основному, грунтувалися на співі, демонструючи в буттєвих сюжетах надповсякденний зміст повсякденного. Другі ж тяжіли до історичної тематики, насичені танцювальними й акробатичними номерами, демонструють прийоми ушу. Але спільним моментом для обох типів п'єс $\epsilon$ гимнічно-ошатна настройка, надповсякденна значимість того що відбувається, навіть якщо це сучасний сюжет і позбавлений глибоких конфліктних подійових ситуацій. Звідси - резюме Лю Бінцяна: «Як бачимо, вистава 'Жіночий батальйон Червоної армії' демонструє тип 'військової' п'єси, відчого хореографічний варіант іiі виявився в центрі уваги постановників» [там же, 310].

Наведені факти сходження китайського театрального мистецтва мали своєю паралеллю успіхи китайських піаністів у світовому розкладі, що забезпечило їм одне з лідерствуючих положень у планетарних масштабах до початку XXI сторіччя. Зіркою світового значення визначився Лю Шикунь, лауреат Конкурсу Чайковського в Москві, що постраждав у період Культурної революції, але дивний прорив саме в піаністичній сфері був здійснений. І спадкоємцями цієї фортепіанної слави Китаю кінця 1950-х - початку 1960-х років стала ціла плеяда блискучих піаністів, які затвердилися в міжнародній якості в 1970-ті - 2000-ті рр.: Лі Юнді, Лан Лан, Ванг Юеджа і багато інших.

Політичні й економічні потрясіння, якими лихоманило Китай у десятиліття, що настали після Революції 1960-х років, не закреслювали того високого змісту, що відзначив музичні й художні досягнення в цілому великої країни, у яку згодом влилися сили, сформовані регіонально, а саме, 
музичні напрацювання Тайваню як частини Китаю на певному історичному відрізку автономізованого у своєму розвитку й того, що не приймав ті або інші посилання материкової складової китайського образу мислення.

Між 1950-ми й 1960-ми роками Тайвань пережив значний економічний ріст, завдяки економічній програмі допомоги Сполучених Штатів. Темпи зростання промислового виробництва досягали $10 \%$ у рік, і поступово ріст багатства привів до рішучих соціальних змін. Протягом наступних двох десятиліть виникли два літературних рухи, які мали вплив на суспільну думку, на політичні й соціальні аспекти, i, тим більше, безпосередньо впливали на сферу мистецтва.

Точно так само як автори материкової музики, що мала попит на Тайвані, користувалися сильною підтримкою Націоналістичного уряду, на літературній сцені домінували антикомуністичні й антияпонські статті й літературні опуси авторів, що писали на істинному мандаринському наріччі китайської мови. Незважаючи на безсумнівну літературну цінність цих робіт, нове молоде покоління модерністів кинуло виклик реалізму, який вони вважали плином, що здійснювало ідеологічний контроль над письменниками.

Нове покоління тайваньскої інтелігенції прийняло західну філософію й відхилило нав'язувані соціальні установки, засновані на конфуціанських традиціях, установлені тисячу років тому. Піддавшись впливу фрейдистського психоаналізу й західного екзистенціалізму, тайваньські письменники-модерністи робили сильний акцент на раціоналізмі, на людському поводженні й боротьбі із забобонами. Тенденція, відома як "Сучасний літературний рух 60-их", стала настільки домінуючою, що швидко поширилася майже на всі області мистецтва, на живопис, театр і музику.

У цей час, в 1960-ті роки, композитор Ченг Хукеу дав перший сольний концерт, що складався тільки із його творів, - і тим ознаменував нову еру в розвитку тайваньской музики.

Коли в 1959 році Ченг Хукеу повернувся на Тайвань із Парижа, де він одержав свою освіту, більшість тайваньських композиторів усе ще застосовували традиційні, тональні композиційні методики, які дісталися їм у спадщину від китайських професорів з материка. Таким чином, стиль Ченга Хукеу, що широко використовував композиційні методики XX сторіччя, розглядався як сміливий і новаторський експеримент.

Ченг Хукеу згадував: "... подібна техніка композиторського письма була абсолютно новою мовою для сучасної музики на Тайвані... Незважаючи на те, що сучасні методи композиції вже існували більш, ніж половину сторіччя... на Тайвані це все було ще невідомо..." [5, 38].

Після концерту з авторських творів у газетах і журналах буквально протягом половини місяця з'явилися більше десяти критичних відгуків. Ченг Хукеу запросив трьох інших композиторів i організував музичний колектив, назва якого дослівно переводиться як "Майстерня по виготовленню музики". Ця група видавала місцеві музичні композиції й представила за період між 1961-1972 рр. у цілому вісім програм нових музичних концертів. Слідом за колективом Ченга Хукеу з'явилися інші групи композиторів, такі як "Нова музична прем'єра", " Жанг-Ланг" (річкова хвиля), "Ву Рен" (п'ять чоловіків) і група "Соняшник".

Композиторські прийоми, які застосовувалися авторами протягом того періоду, були сформовані під впливом музики Дебюссі, Бартока та інших композиторів початку XX сторіччя. Справедливості заради нагадуємо, що західний напрямок у розвитку тайваньської музики «запізнювався», щонайменше, на половину сторіччя. Більш ранній стиль змішання класичної тональної системи 3 пентатонними мелодіями використовувався рідко, а то й повністю був ігнорований композиторами нової хвилі.

Цікаво відзначити, що в цей період тотальної модернізації й "вестернізації" музичну сцену, на відміну від інших областей мистецтва, майже не торкнув ідеологічний аспект, і композитори були більше залучені в технічну сторону творчого процесу. Щоб виражати особистісні відчуття й зберегти культурну ідентичність, композитори продовжували використовувати китайську музику, літературу й картини для свого натхнення.

У більше пізні роки Ченг Хукеу назвав пануючі композиційні стилі цього періоду "китайською модернізацією музики", тенденція модернізації в 1960-ті роки стала важливим поворотним моментом у розвитку західної музики наТайвані.

Наприкінці 1960-их деякі автори, вчені й художники почали противитися перевазі прозахідного модернізму й хтіли привнести в мистецтво власне усвідомлення національного середовища й культури. Суперечки між угрупованнями привели до початку так званої "Сучасної поетичної дискусії" (1972 рік), і ці суперечки не вщухали до кінця десятиліття. Фактично, це явище відбило зростаюче розуміння культурної ідентичності в середовищі артистів і інтелігенції протягом 70-их, і пізніше було названо тенденцією "Повернення до рідних коренів". 
Між 1966 і 1967 pp. Ченг Хукеу і Вэй Ляньши ініцювали безпрецедентний проект "Збір тайванських народних пісень", найбільш масштабний захід щодо збору народних пісень із тих, що були здійснені на Тайвані. Їх колекції включали народні пісні й від автохтоонних шарів, і від китайців провінції Ханипуй. Цей проект мав прямий вплив на естетичні погляди композиторів, на тематику створюваних музичних творів, - i зібрана колекція залишається дотепер одним 3 найважливіших ресурсів, з яких черпають натхнення місцеві музиканти-фахівці.

Особливо відзначаємо збіг зазначених заходів охорони національно-регіональних якостей рідного мистецтва з тенденціями «провінціалізму» у художньому світі, що найбільш демонстративно відбито в коріннях рок-н-ролу, визначеного творчістю майстрів американського Півдня й Заходу, що соціально-культурно третирувалися в США після поразки південців у війні 1863-1865 pp.

Після того, як кілька трохи раніше створених музичних колективів були розформовані, Ченг Хукеу прийняв на роботу одинадцять молодих композиторів, серед яких був Ма Шулонг. Це було здійснене заради заснування організації, яку він назвав "Китайською асоціацією дослідження сучасної музики" (1969 рік). Асоціація була покликана полегшити спілкування й взаємодію між тайваньськими композиторами. Пізніше асоціація стала республіканським китайським відділенням міжнародної організації - "Ліги азіатських композиторів" (1973), і до останніх років була центром впливу тайваньских композиторів на їх культурне оточення.

Ще одна важлива організація, що подала свій внесок у рух "Повернення до рідних коренів", Театр танцю "Ворота в хмарах", заснований Хуай Минлин в 1973 році. За ці роки Лин замовляла багатьом тайваньським композиторам танцювальну музику, щоб підняти рівень і дух тайваньського мистецтва.

Як бачимо, саме гасло руху "Повернення до рідних коренів" термінологічно й смислово співвідноситься з таким всекитайським явищем початку XX століття, як «література рідних місць». У роботі О.Маркової [7, 76-77] вказано на співвіднесеність стильових значеннсвостей епохи символізму, тобто кінця XIX - початку XX століття, 3 «неосимволістськими» (за Марковою ж) проявами постмодерну-поставангарду на грані XX i XXI ст. Проверистський художній прошарок Китаю початку минулого століття виявився парадоксально «оберненим» у співвіднесенні 3 регіоналістським принципом на Тайвані, позначеним як рух «Повернення до рідних коренів».

I якщо «література рідних місць» декларувала літературоцентризм у художній програмі, виходячи на музичні явища через театр, то тайванська увага до «рідних корінь», як бачимо, мала змішаний літературно-музичний характер, але музичне в ньому все-таки виявилося на першому плані у вигляді фольклористських устремлінь у творчих шуканнях.

Ідеологічний зміст "Повернення до рідних коренів" серед композиторів поступово був втрачений до кінця 1970-их. Музикознавець Джирен Жанг відзначав:

«... рух "повернення до рідних корінь" не досягнув успіху на грунті об'єднання національних традицій 3 реальною дійсністю. Багато хто 3 людей прийшли до думки, що невні спроби використання народних музичних матеріалів фактично були тільки поверхневими комбінаціями псевдонаціональної і сучасницької форм, втрачаючи, таким чином, органічну енергію, властиву кожній 3 них» $[5,42]$.

Більше молоді композитори також повернулися на Тайвань після 80-х рр., одержавши освіту в західних країнах. Композиторська техніка тайваньських музикантів-фахівців стала більш зрілою, а довгі роки експериментів i музичних досліджень дозволили їм створити пізнаваний стиль $\mathrm{i}$ неповторний композиторський почерк. Міф національної винятковості був переглянутий i пристосований до умов сучасного швидко змінюваного суспільства. Таким чином сучасна тайваньська музика після 80-х років XX століття взагалі стала демонструвати космополітичні стильові показники.

Організація "сучасного літературного руху" визначила в остаточному підсумку народження оригінальної тайваньської музики й самостійність ії шляху в мистецтві. Такою $є$ логіка багатьох напрямків у художній творчості, у тому числі це шлях класицизму й бароко в європейському мистецтві, що народжувалися в умовах обмеженого соціального замовлення, але поступово охоплюючи всенаціональний i всеєвропейський простір. Таким само шляхом просувалися вищезгаданий веристський й проверистський стильовий прошарок китайської «літератури рідних місць» в культурних антитезах минулого сторіччя. Регіональні здобутки музичного мистецтва Тайваню 1960-х - 1980-х років стали базою міцного мистецького творчого сьогодення Китаю й культурного оточення останнього. 
Наукова новизна дослідження визначається новаційністю ідеї тайваньского стилістичного внеску в загальнокитайський стильовий запас, у якому офіційний академізм і вірність національним умовам породили глибоко оригінальну версію модерну ХХ століття.

Висновки. Історичними шляхами центральний Китай у XX в., насамперед, його великі культурно-художні центри Пекін і Шанхай, виявилися спрямованими на проєвропейські шляхи в музично-освітній системі по лінії зв'язку з Росією як військовою спільницею у війні з Японією ще від початку XX століття й аж до подій Другої світової війни (див.діяльність М.Черепнина в Китаї). Тайвань у художньому аспекті позначився становленням в істотній опорі на західні впливи. Внутрішньокитайські культурні показники визначили самостійність Тайваню в чуйності до вокальнопісенної й фортепианної сфер, тоді як в області театру відповідні акценти позначилися окрім Тайваню.

\section{Jimepamypa}

1. Асафьев Б. Музыкальная форма как процесс. Москва-Ленинград: Музыка, 1971. 379 с.

2. Батанов В.Ю. Универсализм композиторской личности в музыкальном искусстве XX - начала XXI вв.: дисс. ... канд. искусств., специальность 17.00 .03 - муз. искусство. Одесская нац. муз. академия имени А.В.Неждановой. Одесса, 2016. 186 с.

3. Виноградова Е., Желоховцев А. Китайская музыка // Музыкальная энциклопедия в 6-ти томах. Т. 2. M., 1974. C.807-815.

4. Лю Бинцян. Музыкально-исторические параллели развития искусства Китая и Европы. Монография по истории культуры для музыкальных академий, университетов и вузов искусства. Одесса: Астропринт, 2014. $440 \mathrm{c}$.

5. Лю Кетин. Современная фортепианная школа Тайваня в аналогиях к европейскому искусству XX века.: дисс. ... канд.искусствов., спец. 17.00.03. Одесса, 2017. 180 с.

6. Ма Вей. Концепція форми в музиці Китаю і Європи: аспекти композиції та виконавства. автореф. дис. ... канд. мист. Одеса, 2004. 17 с.

7. Маркова Е. Проблемы музыкальнгой культурологии. Одесса: Астропринт, 2006. С. 99-134.

8. Сюй Чэнбэй. Пекинская опера. Серия «Духовная культура Китая» / Пер. Сан Хуа, Хэ Жу. Харбин: Межконтинентальное издательство Китая, 2003. 136 с.

\section{Reference}

1. Asafiev B. (1971). Music form as process. Moscow-Leningrad: Muzyka. 379 p. [in Russian].

2. Batanov V. (2016). Universalism of composer personalities in music art XX - begin XXI ct. Candidate's thesis, spec.17.00.03 - mus.art.Odessa state music academy of the name A.V.Nezhdanova. Odessa [in Ukrainian].

3. Vinogradova E., Zhelohovcev A. (1974). Chinese music Music encyclopedia in 6 volumes. V. 2. Moscow: Sov.encyklopedija, P.807-815[in Russian].

4. Liu Binchan (2014). Music-history parallels of the development of the art to China and Europe. Monograph on histories of the culture for music academy, university and high school art. Odessa, Astroprint [in Ukrainian].

5. Liu Ke Ting (2017). Modern Taiwan Piano School in analogies to European art of the 20th century. Dissertation for the degree of PhD of Arts by specialty 17.00.03 - Musical Art. Odessa National A. V. Nezhdanova Academy of Music, Odessa, [in Ukraine].

6. Ma Vei (2004). Concept of the form in music of China and Europe: aspects to compositions and performance. Candidate's thesis. Spec.17.00.03. Odessa national music academy of the name A.V.Nezhdanova. Odessa [in Ukrainian].

7. Markova E. (2012). The problem of music culturology. Odessa, Astroprint, P. 99-134[in Ukrainian].

8. Siu Cheng Bey (2003). Pen Cing opera. Series "Spiritual culture of China". Transfer San Hua, He Zhu. Har Bing, Mezhkontinentalnoje izdat.Kitaya [in China]. 